\title{
The Effect of Spiritual Counseling and Hope Therapy Training on Palliative Care Self-efficacy of Nursing Students of Urmia Azad University
}

\author{
Elahe Radman ${ }^{1}$, Monireh Rezaee ${ }^{* 2}$, Esfandyar Baljani ${ }^{3}$
}

1. Department of Nursing, Urmia Branch, Islamic Azad University, Urmia, Iran

2. Department of Midwifery, Urmia Branch, Islamic Azad University, Urmia, Iran

3. Department of Nursing, Urmia Branch, Islamic Azad University, Urmia, Iran

Article Info
Received: $2020 / 02 / 16$
Accepted: $2020 / 08 / 03 ;$
Published Online: $2020 / 10 / 01$
dof $10.30699 /$ ajnmc. 29.1 .45
Original Article
Use your device to scan
and read the article online
D.

\begin{abstract}
Introduction: Palliative care is of great importance for improving the quality of life of chronic patients and providing palliative care education to nurses is one of the important ways in the development of such care. The purpose of this study was to determine the effect of spiritual counseling and hope therapy on self-efficacy of palliative care of nursing students.
\end{abstract}

Methods: This was an experimental study. The statistical population consisted of senior nursing students of Urmia Azad University, Urmia, Iran. The samples were selected from the complete list of students using census sampling and then divided into intervention and control groups. Data were collected using a two-part questionnaire including demographic information and clinical practice self-efficacy questionnaire. The intervention group received 9 sessions of training on hope and spiritual counseling but the intervention group did not receive training. The intervention results were regathered after 9 sessions using the same questionnaire.

Results: Independent-sample t-test showed that the mean scores of overall clinical self-efficacy scores of nursing students before spiritual counseling and hope therapy were not significantly different $(P>0.05)$, while the same test showed that there was a significant difference between the mean scores of clinical self-efficacy between intervention and control groups after spiritual counseling and hope therapy program ( $\mathrm{t}=63.6, P=0.02)$.

Conclusion: The results of this study showed that spiritual counseling and hope therapy training is effective on self-efficacy of palliative care of nursing students and can be used in palliative care teaching and pattern-based nursing care for a variety of patients.

Keywords: Spiritual counseling, Hope therapy, Palliative care, Nursing student, Selfefficacy

How to Cite This Article:

Radman E, Rezaee M, Baljani E. The Effect of Spiritual Counseling and Hope Therapy Training on Palliative Care Self-efficacy of Nursing Students of Urmia Azad University. Avicenna J Nurs Midwifery Care. 2020; 29 (1) :45-52 
تأثير آموزش برنامةٔ مشاورة معنوى و اميددرمانى بر خودكار آمدى مراقبتهاى تسكينى دانشجويان يرستارى دانشعاه آزاد اروميه

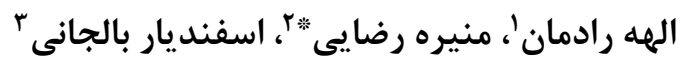

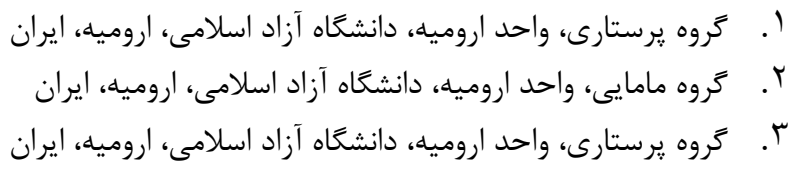

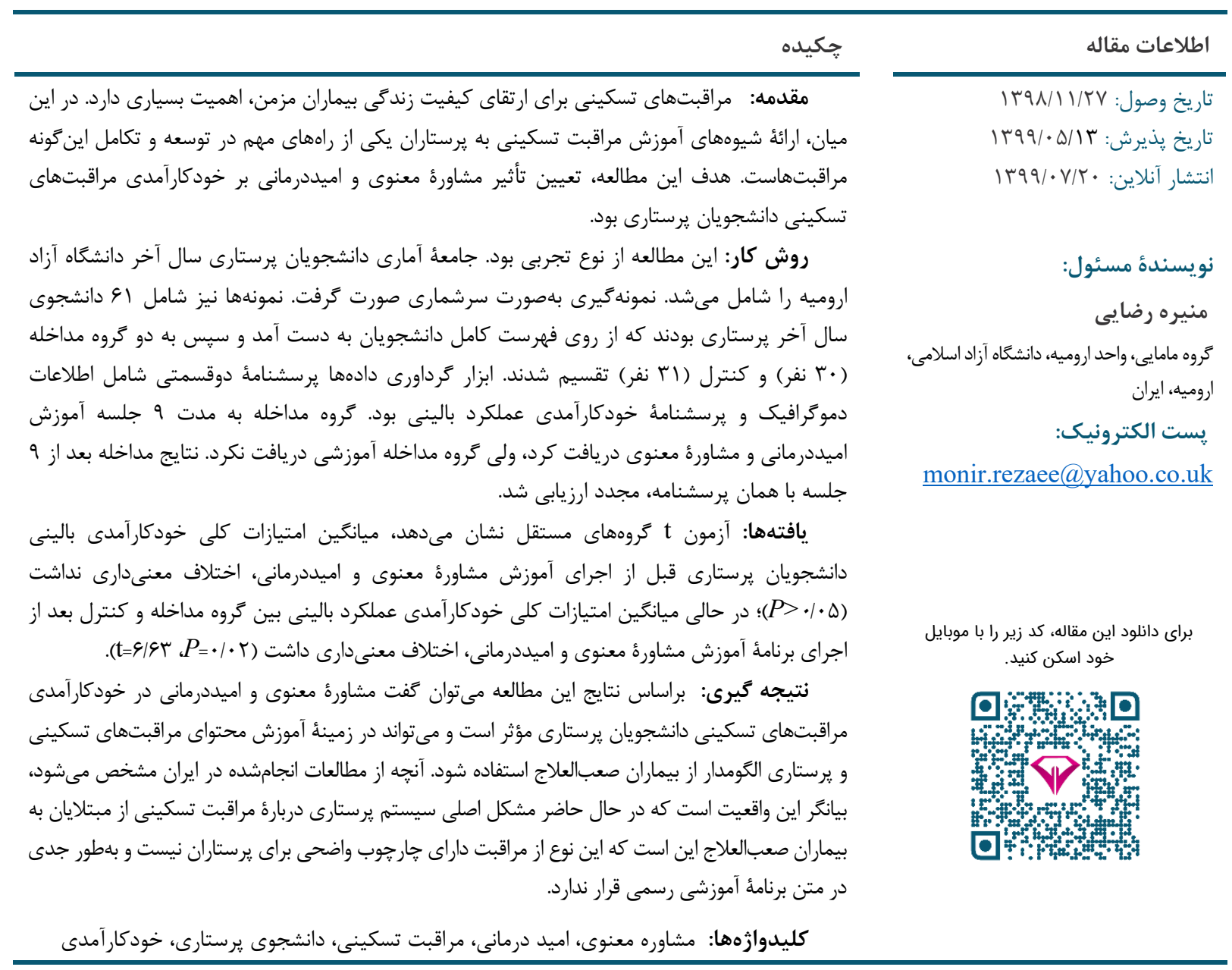

مقدمه

بيمارىهاى مزمنى كه به بيمارىهاى مرحلة نهايى' منجر

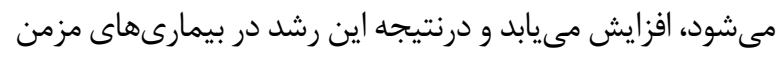

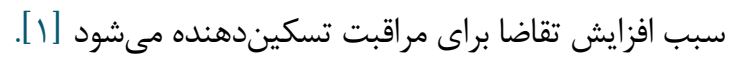
در دورة طولانىمدت بيمارى مزمن و صعبالعلاج، بيماران

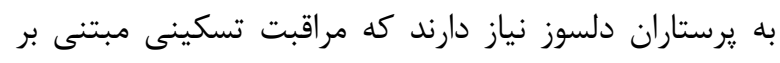

مراقبت تسكينى هنر و علم يرستاران است كه بر كيفيت و

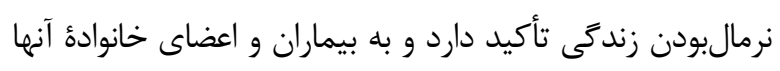

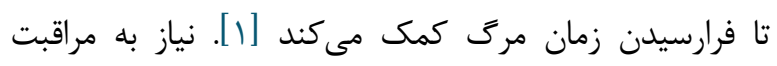

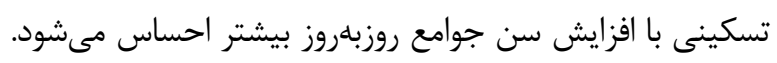

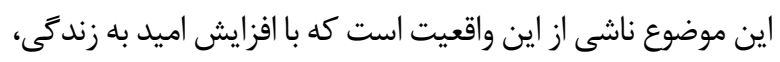

1. End-Stage Illness 
مطالعات قبلى در زمينهُ تأثير معنويت و اميد بر بيماران

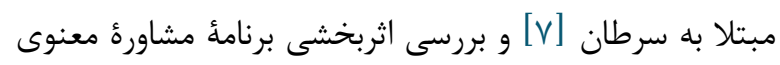

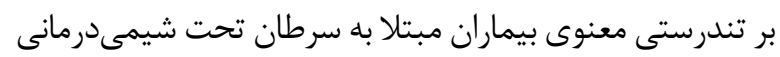

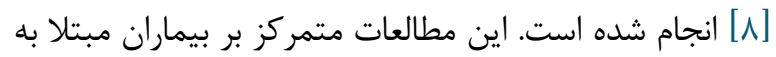

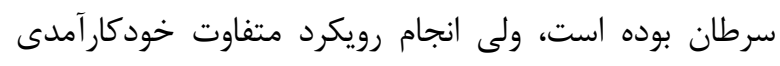

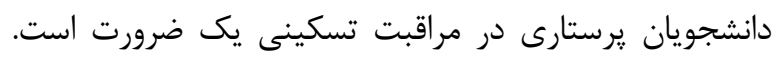

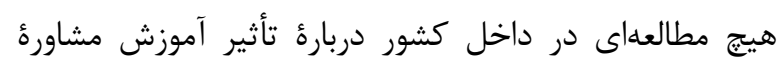

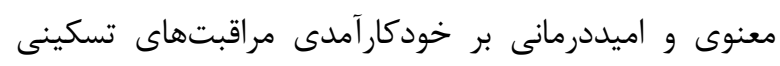
دانشجويان يرستارى انجام نشده است. از آنجا كه دانشجويان ماندان

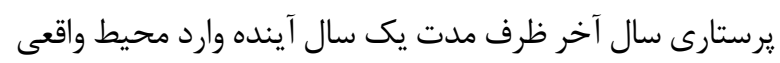

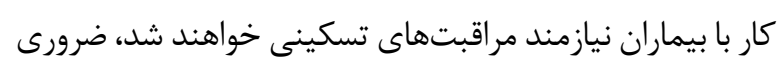

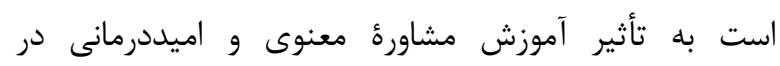

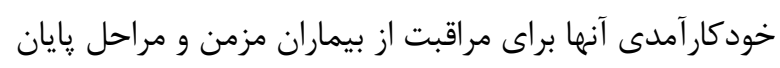

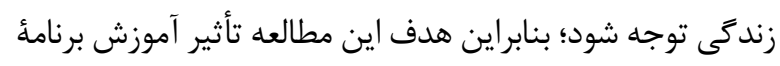

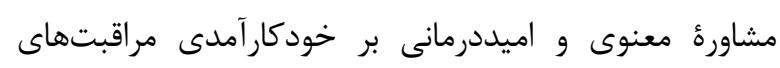
تسكينى دانشجويان يرستارى بود.

\section{روش كار}

اين مطالعه از نوع تجربى بود. جامعأ آمارى نيز دانشجويان

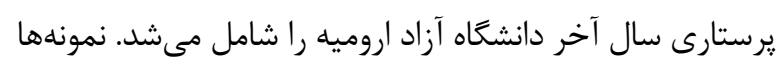

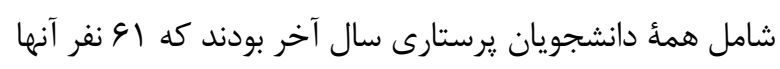

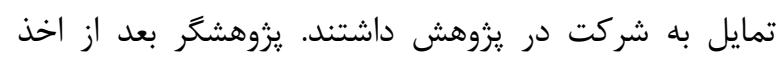

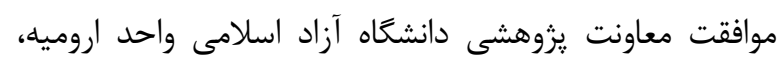

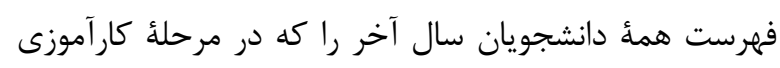

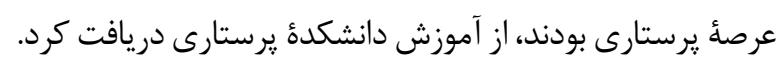

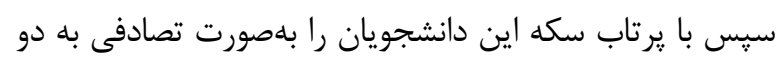

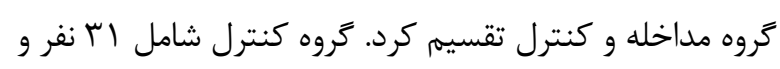

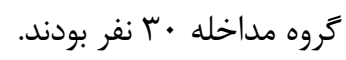

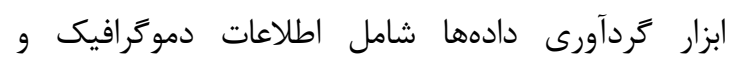

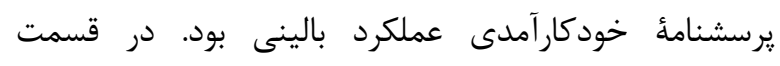

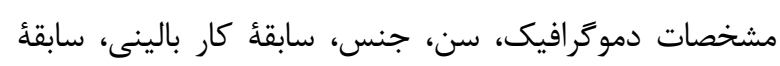

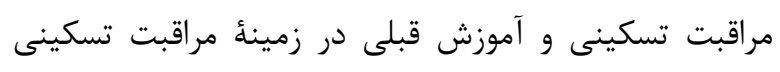

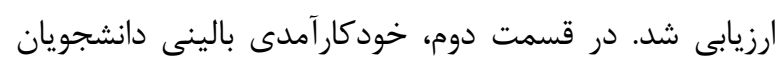

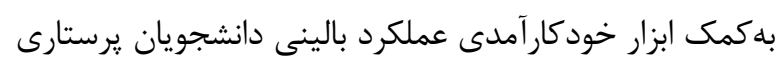

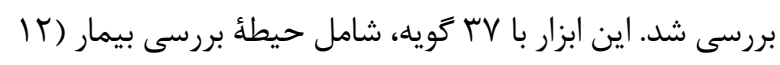

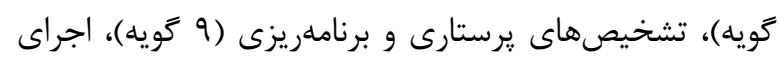

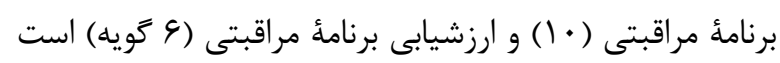

شواهد را انجام دهند؛ بنابراين يرستاران بايد براى اجراى اين

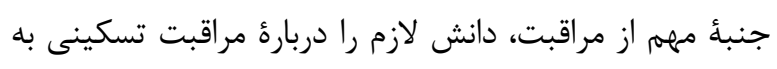

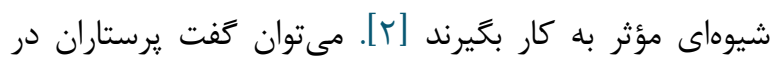

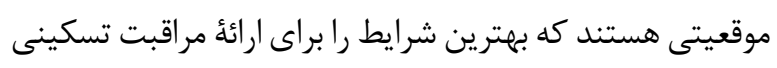

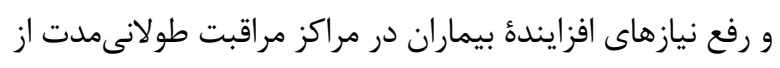

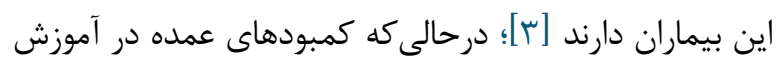

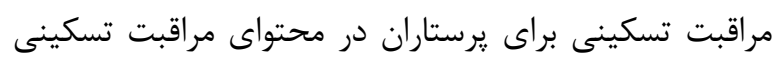

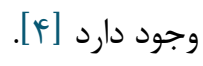
آرستارانى كه در بخشهاى بيمارستان با بيماران مران مراحل

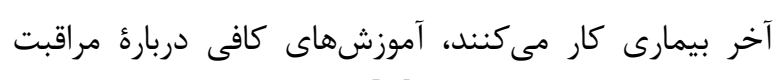

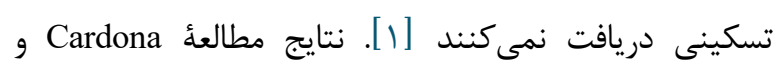

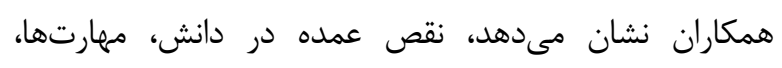

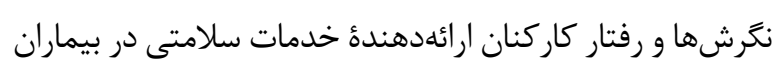

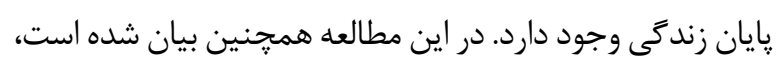

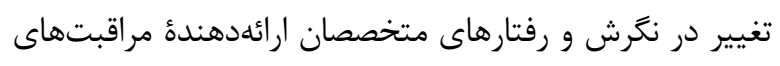

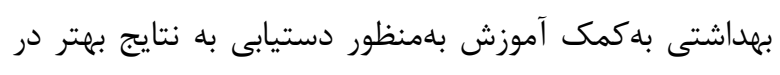

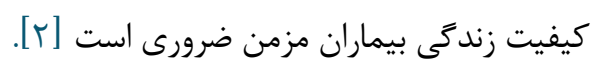

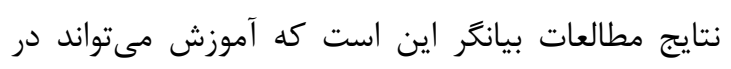

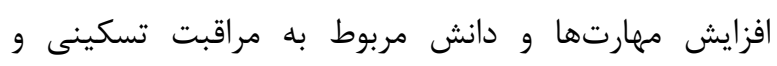

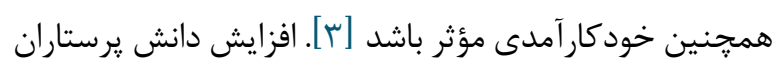

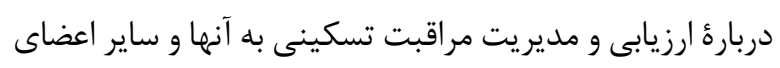

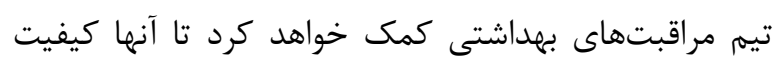

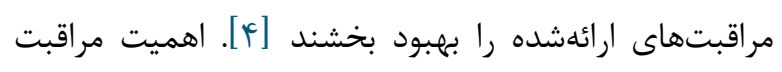
تسكينى در برنامة درسى كارشناسى ارشد دائس دانشجويان

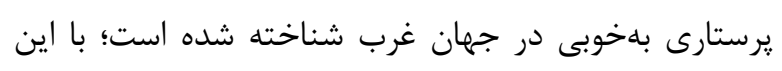

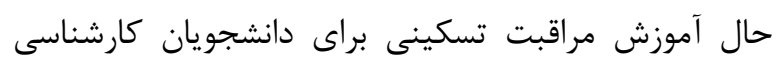

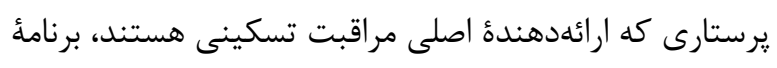

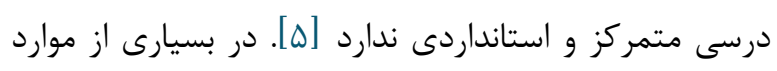

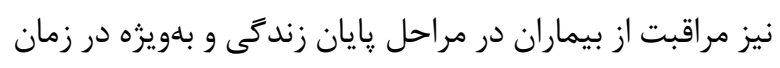

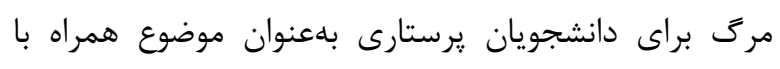

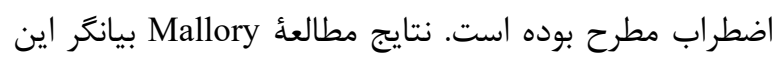

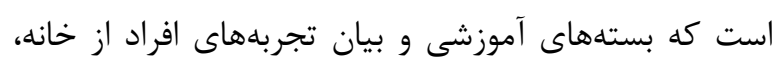

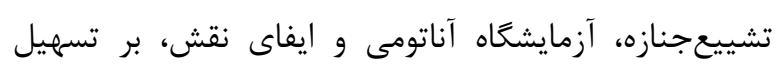

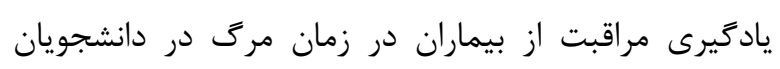

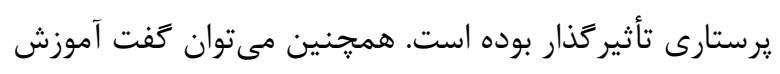

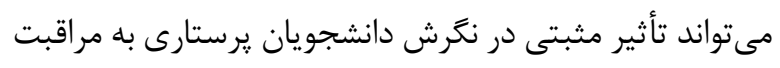

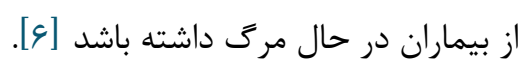


جلسهٔ ششم: آموزش مراحل اميددرمانى و تأثير هركدام بر

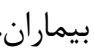

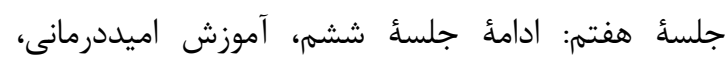

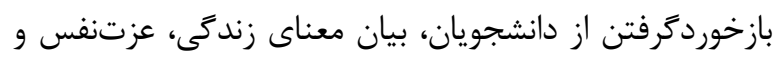

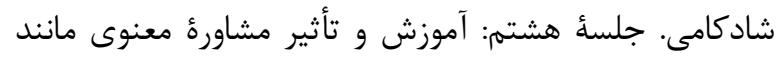

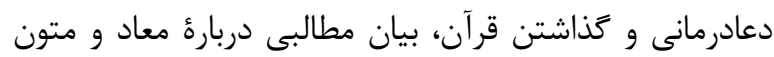

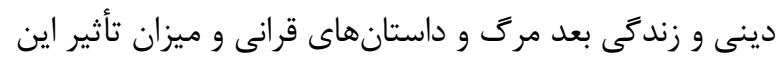

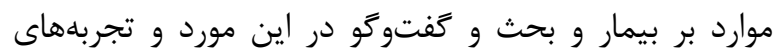
دانشجويان و محقق در اين مورد. جلسأ نهم: جمعبندى كل مطالب ارائهشده، ميزان فوايد مطالب و ارائه يرسشنامه براى يِ يسآزمون. ملاحظات اخلاقى با دادن فرم رضايتنامه قبل از يركردن إن برن يرسشنامه و آموزش به دانشجويان، كسب مجوز از آن شوراى

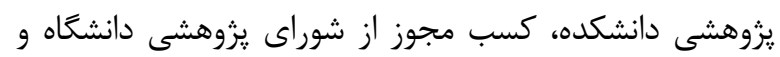
كسب كد اخلاق (IR.IAU.Urmia.Rec.1397.21) به عمل آهد. براى واردكردن و تجزيه و تحليل دادهها از نرمافزار

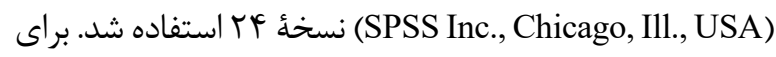
توصيف مشخصههاى دموَر افيك از آمار توصيفى مانند ميانكَين، انحراف معيار، فراوانى مطلق و درصدى استفاده شد. براى تحليل

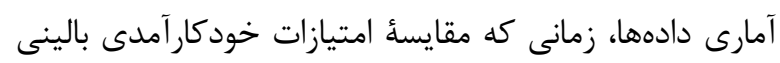

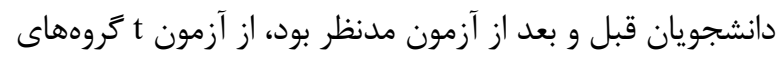
زوج استفاده شد. زمانى كه مقايسٔ امتيازات خودكار آمدى بالينى بين كروه كنترل و مداخله مدنظر بود، از آزمون

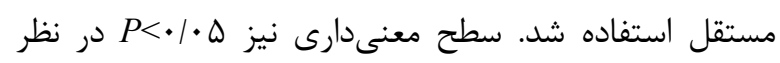
كرفته شد.

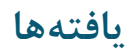

نتايج مطالعٔ حاضر نشان مىدهد، بيشترين فراوانى

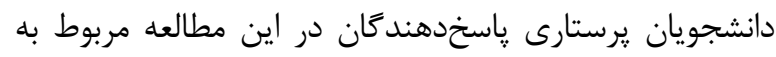

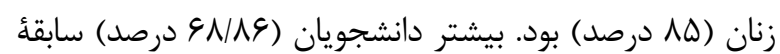

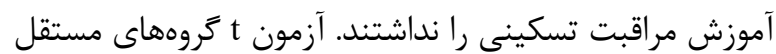

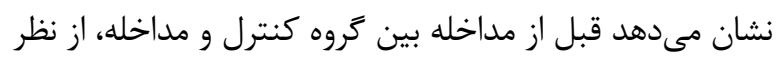

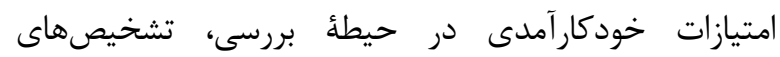

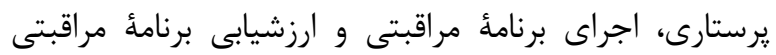

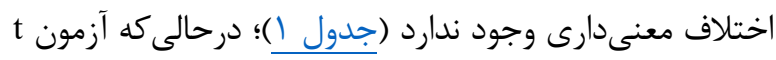

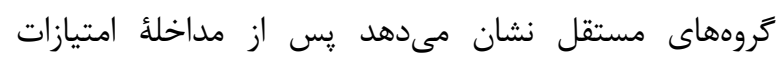

كه در مقياس وينجدجهاى ليكرت تدوين شده است. اين

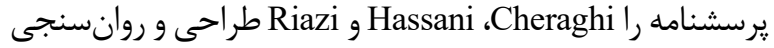
كردند. روايى يرسشنامه از طريق اعتبار محتوا و صورى و يايايى آن در مطالعأ مذكور با ضريب آلفاى كرونباخ 99/ • تأييد شده

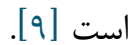
روش كار به اين صورت بود كه در مرحله اول نمونه كيرى،

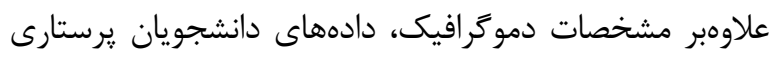

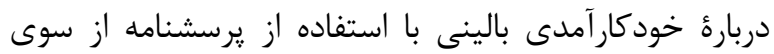

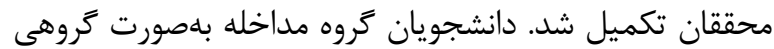

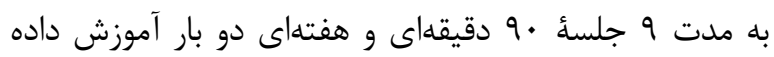
شدند. محتواى آموزشى برَرفته از مطالعات Shekarabi-Ahari

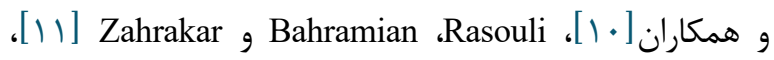
و Baljani بود. آموزش به روش سخنرانى و با استفاده از دستگاه ويدائو يروزكتور و امكانات كلاس درسى صورت كرفت. همجنين در در

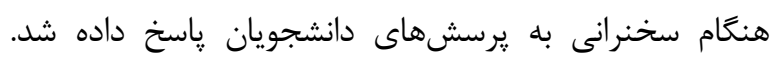

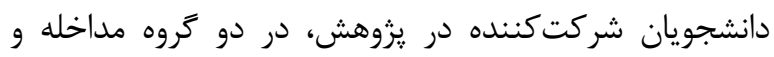

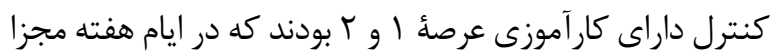

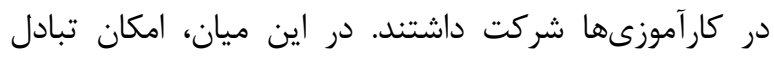

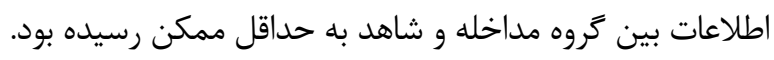

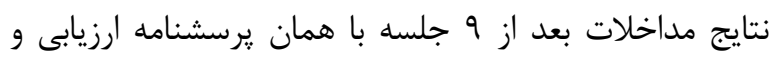

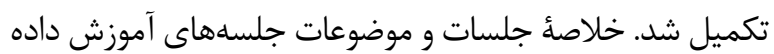
شده در كروه مداخله به شرح زير است جلسئ اول: آشنايى محقق و دانشجويان با يكديكر. هدف آنداز

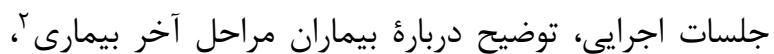
عوامل مؤثر بر اين امر و نيازهاى مربوط به به اين بيماران بوان بودان

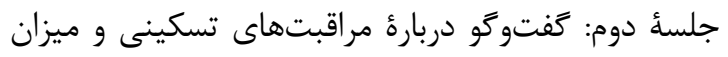
اطلاع دانشجويان در اين مورد و ميزان كارايى مراقبتهاى درئ درائ تسكينى در دانش حرفئ يرستارى.

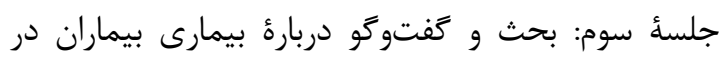

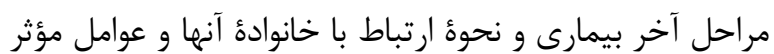

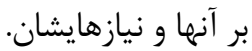
جلسؤ جهارم: آشنايى با مشاورة معنوى و منظور از آن آن و نحوة استفاده از آن در يرستارى.

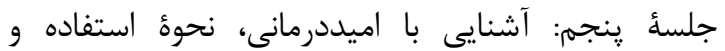
تحقيقات انجامشده در بيماران صعبالعلاج.

${ }^{2}$. End stage 
الهه رادمان و همكاران

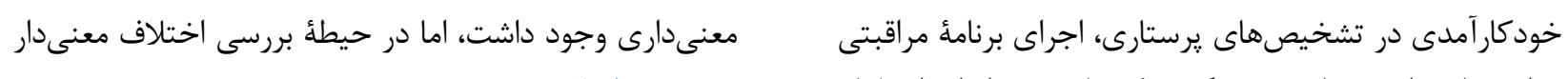

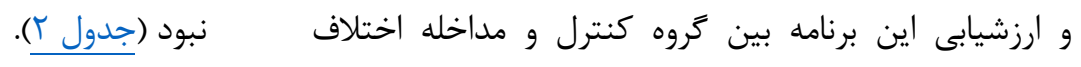

جدول ا. مقايسٔ امتيازات خودكار آمدى مراقبت تسكينى دانشجويان برستارى سال آخر قبل از مداخله

\begin{tabular}{|c|c|c|c|c|c|}
\hline$P$ & $\mathrm{t}$ & انحراف معيار & ميانَين & كروه & خودكار آمدى \\
\hline \multirow{2}{*}{$\cdot / M F$} & \multirow{2}{*}{$\cdot / v 1$} & $4 / 4$ & $r r / T F$ & كنترل & \multirow{2}{*}{ بررسى بيمار } \\
\hline & & $\mathrm{V} / \mathrm{l}$. & rT/FA & مداخله & \\
\hline \multirow[t]{2}{*}{$\cdot / V T$} & \multirow[t]{2}{*}{$1 / \% 4$} & $\Delta / r \Delta$ & $r \Delta / 1 \Lambda$ & كنترل & \multirow{2}{*}{ تشخيصهاى } \\
\hline & & p/q4 & $r \Delta / v V$ & مداخله & \\
\hline \multirow[b]{2}{*}{$\cdot / \cdot \wedge F$} & \multirow[b]{2}{*}{$-F / \cdot r F$} & $\Delta / v F$ & $r q / q r$ & كنترل & \multirow[b]{2}{*}{ اجراى برنامةٔ مراقبتى } \\
\hline & & $9 / \pi$. & TN/VI & مداخله & \\
\hline \multirow[t]{2}{*}{. } & \multirow[t]{2}{*}{ r/q } & $r / q$. & IV/TE & كنترل & \multirow{2}{*}{ ارزشيابى برنامة } \\
\hline & & $\Delta / v 1$ & $19 / 4 \Delta$ & مداخله & \\
\hline
\end{tabular}

جدول r. مقايسةٔ امتيازات خودكار آمدى مراقبت تسكينى دانشجويان يرستارى سال آخر بعد از مداخله

\begin{tabular}{|c|c|c|c|c|c|}
\hline$P$ & $\mathrm{t}$ & انحراف معيار & ميانگَين & 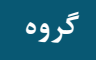 & خودكار آمدى بالينى \\
\hline \multirow{2}{*}{$\cdot / 4 q$} & \multirow{2}{*}{$r / 9 F$} & $V / \pi$ & HF/IF & 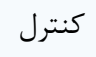 & \multirow{2}{*}{ بررسى بيمار } \\
\hline & & $4 / 11$ & $r \Delta / f r$ & مداخله & \\
\hline \multirow{2}{*}{$.1 \cdot F T$} & \multirow{2}{*}{$r / r F$} & r & $r \varepsilon / 10$ & كنترل & \multirow{2}{*}{ تشخيصهاى يرستارى } \\
\hline & & $\Delta / 91$ & $r \cdot / V r$ & مداخله & \\
\hline \multirow{2}{*}{$\cdot / \cdot 1$} & \multirow{2}{*}{91.19} & $\Delta / V I$ & $r \cdot / f q$ & كنترل & \multirow{2}{*}{ اجراى برنامةٔ مراقبتى } \\
\hline & & V/Tr & $r \omega / 4 q$ & مداخله & \\
\hline \multirow{2}{*}{$\cdot 1 \cdot r q$} & \multirow{2}{*}{$\cdot / N r$} & $\Delta / \&$ & $\mid 8 / 48$ & كنترل & \multirow{2}{*}{ ارزشيابى برنامئ مراقبتى } \\
\hline & & $\varepsilon|f|$ & Tr/Ta & مداخله & \\
\hline
\end{tabular}

بحث

دانشجويان يرستارى بررسى نكرده است، در مطالعات قبلى، تأثير مشاورة معنوى و تأثير اميددرمانى بر متغير نكرده است در مطاى كيفيت زنداتى قبلى، تانير

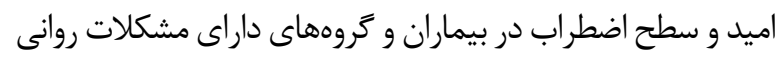

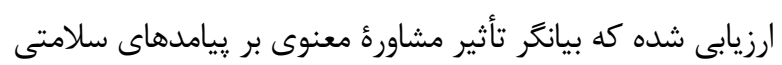

يافتههاى اين مطالعه نشان مىدهد، آموزش برنامة مشاورة

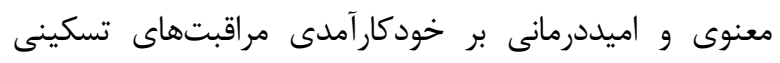

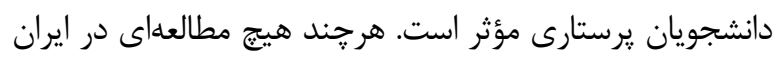

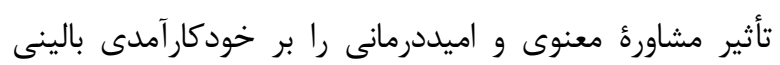


•ه آموزش برنامةٔ مشاورة معنوى و اميددرمانى بر خودكارآمدى

معنوى را در مراكز تخصصى و عمومى كه در آن بيماران مبتلا به

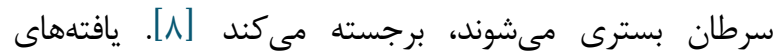
Zahrakarg Bahramian ،Rasouli كروهى بر كيفيت زندگى اين بيماران مؤثر است. همجنين برنامههاى آموزشى- مشاورهاى با نيازهاى درونى و فطرى انسان

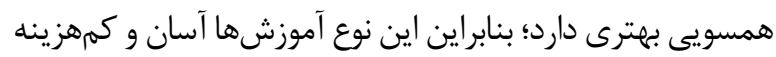

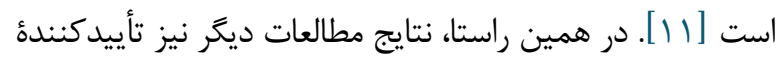
اين موضوع هستند كه آموزش اميددرمانى كروهى در افزايش

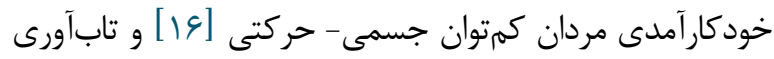

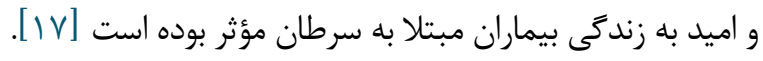

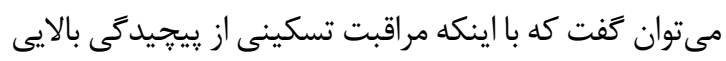
برخوردار است و مفهومى خندبعدى دارد، در كشور ما دانش موجود در زمينأ مراقبت تسكينى بلخوبى تبيين نشده و در متن آنت

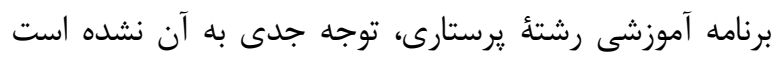

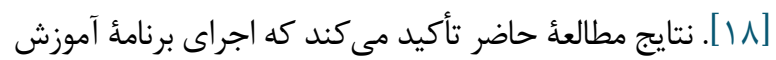
مشاورة معنوى و اميددرمانى در دانشجويان يرستارى مىتواند براى آموزش محتواى مراقبتهاى تسكينى و يرستارى الكَومدار از بيماران صعبالعلاج كاربرد داشته باشد.

\section{نتيجه كيرى}

براساس نتايج اين مطالعه مىتوان كفت مشاوره معنوى و

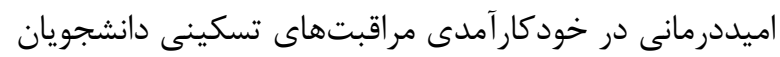

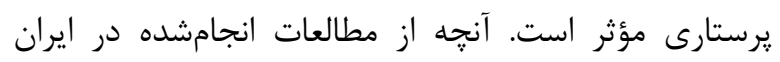

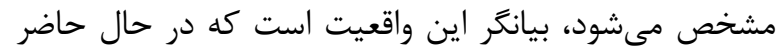

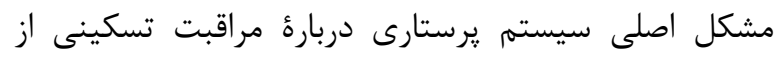

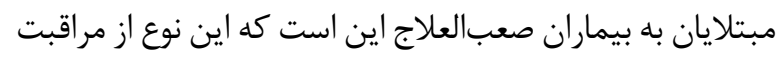

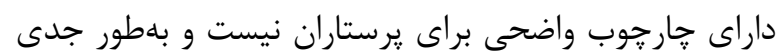

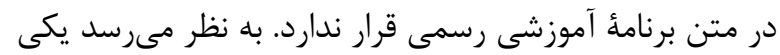

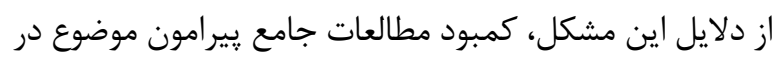

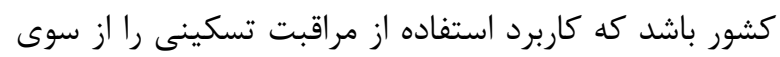
يرستاران براى اين بيماران، محدود مىكند؛ بنابراين نتايج اجراى اين مطالعه مىتواند براى طراحى مدل اجراين محدائ مراقيت

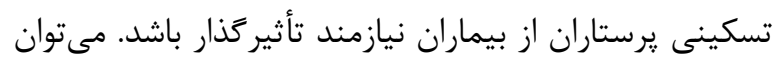
كفت معنويت يكى از عناصر اساسى در آموزش مراقبت تسكينى براى دانشجويان يرستارى و يرستاران در مراقبت از ازئ

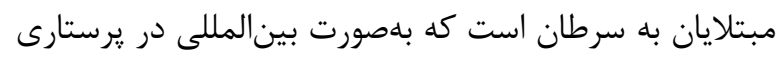

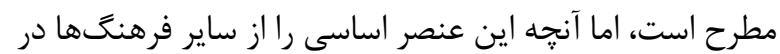

در گروههاى مختلف مددجويان است؛ براى مثال نتايج مطالعهُ Morasai Afaze،Aghajani

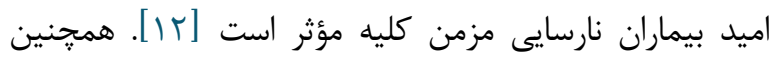
Barlow و Smith ،Martinez معنويت در بهبود كيفيت زندگى بيماران مبتلا به سرطان مؤثر

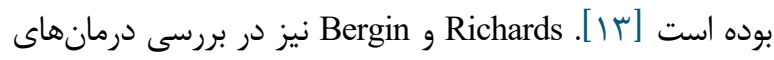

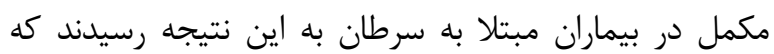

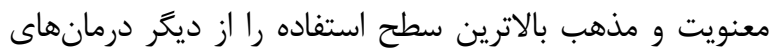

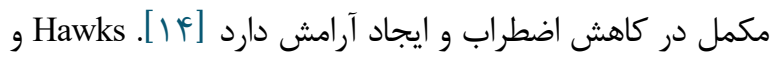

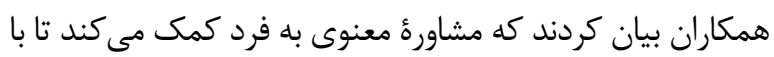
وجود بيمارى و مشكلات فراوان در زندكى بر كمبودها و ناكامى هان فيا تمركز نكنند، بلكه در جستوجوى اميد و هدف در زندگى و اتصال

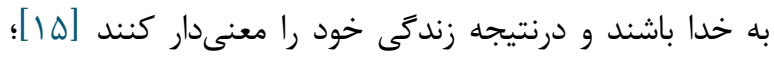

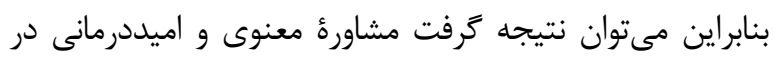
دانشجويان يرستارى مىتواند با داشتن معنا در زندكى، هدفمندي ماندي

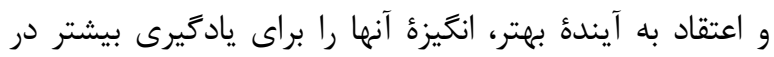

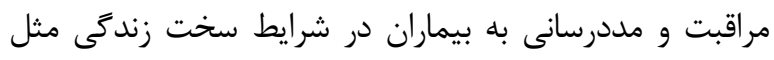
بيمارى افزايش دهد. در اين مطالعه، آموزش مشاوره معنوى و اميددرمانى در

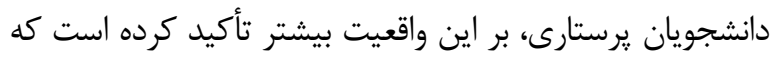

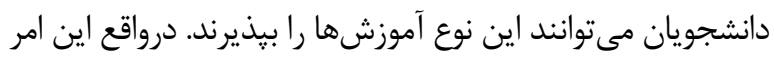

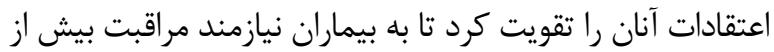
ييش توجه كنند؛ زيرا مشاورههاى معنوى حاوى نكات مهرم اخلاقى هستند كه تعهدات اخلاقى حرفهاى و حساسيت زياد به بهات

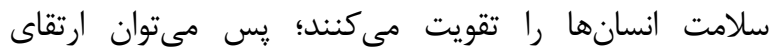
خودكارآمدى بالينى دانشجويان يرستارى در اين مطالعه را به آنهان آنان

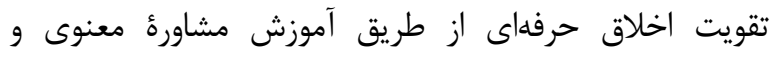

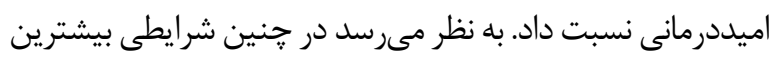
كار مدرسان يرستارى بهعنوان كسانى كه بيشترين فرصت آموزش

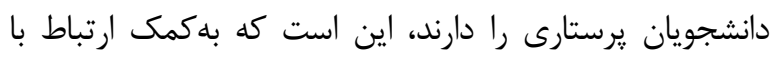

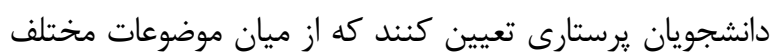
مربوط به معنويت و اميد، كدام مسئله براى دانشجويان يرستارى

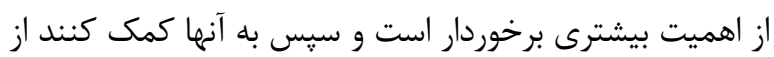
مشاورة تخصصى در اين زمينه بهرهمند شوند.

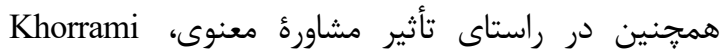
Markani در افزايش سطح تندرستى معنوى بيماران مبتلا به سرطان دارد.

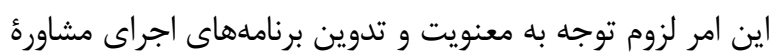




$$
\text { منعارض در منافع منابع مالى منابع مالى اين مطالعه توسط نويسندكان تامين شده است. }
$$

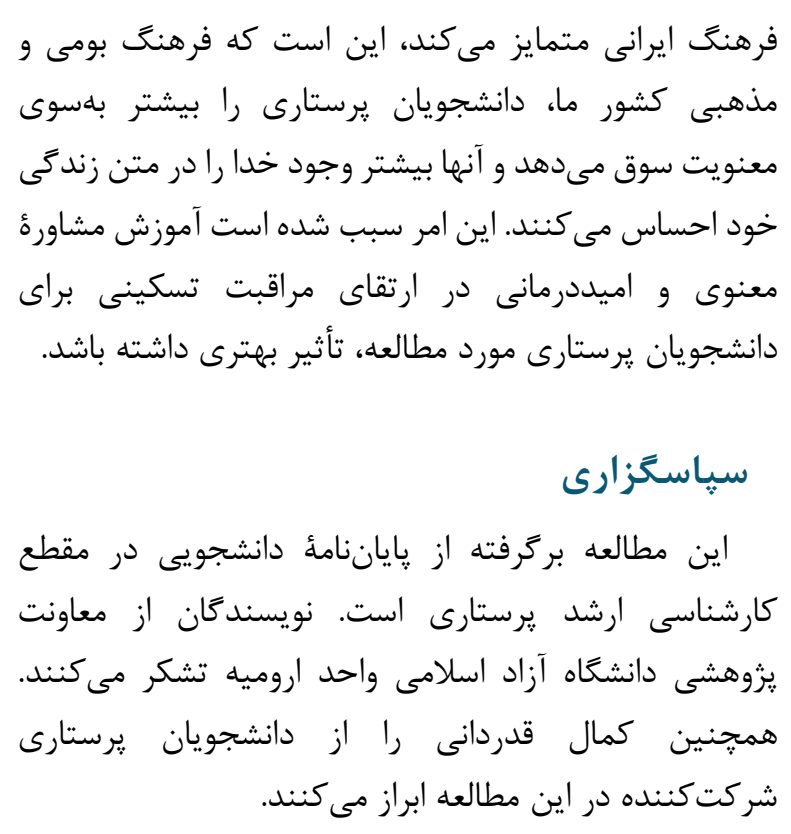

7. Baljani E, Babaloo T, AzimPour A, Rahimi J, Cheraghi R. THE IMPACT OF SPIRITUAL COUNSELING IN HOPE OF PATIENTS WITH CANCER. The J Urmia Nurs Midwifery Fac. 2017;15(9):696-703.

8. Khorrami Markani A, Radfar M, Naseri O, Khalkhali H. Evaluating the effect of spiritual counseling on spiritual well-being of cancer patients undergoing chemotherapy in omid research-treatment hospital in Urmia, in 2014. The J Urmia Nurs Midwifery Fac. 2016;14(7):592-600.

9. Cheraghi F, Hassani P, Riazi H. Correlation study of nursing students' self-efficacy with clinical performance. Avicenna J Nurs Midwif Care. 2011;19(1):35-45.

10. Shekarabi-Ahari G, Younesi J, Borjali A, AnsariDamavandi S. The effectiveness of group hope therapy on hope and depression of mothers with children suffering from cancer in tehran. Iran $\mathrm{J}$ Cancer Prev. 2012;5(4):183-8.

11. Rasouli M, Bahramian J, Zahrakar K. The effect of hope therapy on quality of life in multiple sclerosis patients. 2014.

12. Aghajani M, Afaze MR, Morasai F. The effect of spirituality counseling on anxiety and depression in hemodialysis patients. Evidence Based Care. 2014;3(4):19-28.

13. Martinez JS, Smith TB, Barlow SH. Spiritual interventions in psychotherapy: evaluations by highly religious clients. J Clin Psychol. 2007;63(10):943-60. [DOI:10.1002/jclp.20399] [PMID] component on attitudes toward care of the dying in undergraduate nursing students. J Prof Nurs. 2003;19(5):305-12. [DOI:10.1016/S87557223(03)00094-2]
[DOI:10.1016/S8755-

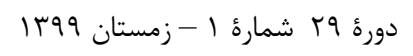

$$
\text { مجله مراقبت يرستارى و مامايى ابنسينا }
$$


14. Richards PS, Bergin AE. A spiritual strategy. Washington, dc: american psychological association. 1997. [DOI:10.1037/10241-001]

15. Hawks SR, Hull ML, Thalman RL, Richins PM. Review of spiritual health: definition, role, and intervention strategies in health promotion. Am J Health Promot. 1995;9(5):371-8. [DOI:10.4278/08901171-9.5.371] [PMID]

16. Sheykholeslami A, Ramezani S. The effectiveness of group hope therapy based on the snyder's theory on self-efficacy of physical and mobility impairments men. Q J Soc Work. 2017;6(1):5-12.

17. Bagheri Zanjani Asl Monfared L, Entesar Foumany G. The effectiveness of group based hope-therapy on increasing resilience and hope in life expectancy in patients with breast cancer. J Health Promot Manag. 2016;5(4):58-64.

18. Iranmanesh S, Razban F, Tirgari B, Zahra G. Nurses' knowledge about palliative care in Southeast Iran. Palliat Supp Care. 2014;12(3):203-10. [DOI:10.1017/S1478951512001058] [PMID] 